\title{
worldview
}

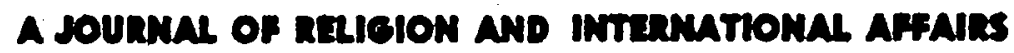

\section{UNREAL ALTERNATIVES}

The great nineteenth century historian, Lord Acton, once stated his personal dilemma in a way which has parallels in, and lessons for, the dilemmas of our time. "I find that people disagree with me," he wrote, "either because they hold that Liberalism is not true, or that Catholicism is not true, or that both cannot be true together. If I could discover anyone who is not included in these categories, I fancy we should get on very well together."

The chief effort of Acton's life was to bridge the polarities which his age had erected between secular freedom and religious belief. In the words of his biographer, Gertrude Himmelfarb: "It was the genius, and the ultimate paradox, of Acton's mind to effect this reconciliation or transcendence by importing religious values into secular affairs and secular values into religious ones. Into politics he brought the moral fervor of the prophet, into religion the humanism of the liberal statesman; and to both he carried the message that power, whether religious or secular, was a degrading, demoralizing, and corrupting force."

In all of this Lord Acton stands as a symbol of the man wiser than his century. And the need of our century, more immediately, of our decade, is precisely for such men. Debates over our national policy, and arguments over our ideologv, are consistently made in terms of irreconcilables: liberal or conservative, idealist or realist, love or justice are the polarities between which we are asked to choose. But choice, alas, is not so easy as the polemicists make it, and if the world is to find any salvation at all, any "solution" for its tortured problems, it will surely be not through a clear choice between the polarities but by a transcendence of them.

In the three and a half years of its existence Worldview's major attempt has been a search for such a reconciliation and transcendence. If the complexity of the thermonuclear age makes anything clear it is the fact that single-minded approaches to its dangers will lead only to disaster; the approaches we make must be multiple and comparative. The present issue of this magazine, which contains a nuclear pacifist's proposals for strategies of non-violent resistance, a Christian realist's critique of nuclear pacifism, and a moralist's review of the important new volume On Thermonuclear War, illustrates the multiple and comparative directions we seek.

A good deal of acrimony and attitudiniz̧ing in our national life might be avoided, and a better start toward viable policies made, if politicians generally realized the present futility of many of the old categories. "Ritualism" in politics is dangerous, whether it be the ritualism of the left or of the right. The old arguments over nationalism and internationalism, for example, are quite settled. History has taken this question out of our hands and we are, as a nation, committed to the pursuit of ever-widening internationalist goals; the only question before us is the manner of pursuing these goals in concert with our allies. The old debates over United States support or nonsupport of the United Nations, of its expending or not expending large sums on foreign aid, of its acceptance or non-acceptance of the aspirations of the emerging nations for independence, have likewise been settled by history, and many of the debates which still rage over these issues have about them a frightening air of unreality.

The more ideological arguments over "survival" or "surrender," "liberation" or "coexistence," "principles" or "negotiations" have an equally unreal air, a quality of disembodiment from the world that confronts us. The point is that, like a Lord Acton, we must recognize that the very posing of the alternatives often traps us in false hood. If we are to survive we must search, constantly, for the truths that lie between. 